\title{
PENERAPAN EVALUASI RINGKAS, RAPI, RESIK, RAWAT, RAJIN PT. INKA (PERSERO) MADIUN
}

\section{IMPLEMENTATION OF SORT, SET, SHINE, STANDARDIZE, SUSTAIN EVALUATION IN PT. INKA (PERSERO)}

\author{
Rio Surya Christian \\ PT. Aneka Gas Industri (Samator Group) \\ E-mail: riosuiyachristian@gmail.com
}

\begin{abstract}
Sort, Set, Shine, Standardize, and Sustain (5S) program is an attempt to minimize or eliminate harm by creating a good workplace culture in the workplace. A comfortable working environment will improve efficiency, productivity, quality, and safety. The 58 program is one of the administrative controls used to prevent accidents. $5 S$ implementation will be reached and applied with support from all sides involved, start from top management, middle management, and low management. The study aims to evaluate the application of $5 S$ in PT. INKA (Persero) Madiun. This study was observational and descriptive research using cross sectional design. The object of this research is all areas in PT. INKA (Persero) Madiun, especially in the workshop / warehouse and open area. The populations are authorized officers in each area. The results showed that the application of 5S at PT. INKA (Persero) Madiun had been done since the first time but there wasn't $5 S$ activity. In 2014, the company's policy on $5 R$ implementation appear so that the $5 S$ implementation was fully supported by the company. Evaluation of the $5 S$ implementation involves 5 areas include open area and workshop area, that already apply $5 S$ well. The concusions of this study was implementation $5 S$ at PT. INKA (Persero) Madiun need to increase and support from top level management
\end{abstract}

Keywords: set, shine, sort, standardize, sustain

\begin{abstract}
ABSTRAK
Program Ringkas, Rapi, Resik, Rawat, Rajin (5R) merupakan upaya untuk meminimalkan atau menghilangkan bahaya dengan membuat budaya kerja yang baik di tempat kerja. Lingkungan kerja yang nyaman akan menciptakan kemudahan dalam bekerja sehingga akan meningkatkan efisiensi, produktivitas, kualitas mutu, dan keselamatan kerja. Penerapan program 5R adalah salah satu dari pengendalian administratif yang digunakan untuk mencegah kecelakaan. Penerapan 5R akan terlaksana dan tercapai dengan dukungan semua pihak perusahaan mulai dari manajemen atas, menengah dan manajemen bawah. Tujuan dari penelitian ini untuk mengevaluasi penerapan 5R di PT. INKA (Persero). Studi ini merupakan penelitian observasional dan bersifat deskriptif dengan menggunakan desain cross sectional. Objek penelitian ini adalah seluruh area di PT. INKA (Persero) Madiun, khususnya pada area workshop/gudang dan area terbuka. Populasi dalam penelitian ini adalah pejabat yang berwenang pada masing-masing area. Hasil penelitian menunjukkan bahwa penerapan 5R di PT. INKA (Persero) sudah dilakukan sejak dahulu tetapi sempat terhenti tanpa ada aktivitas. Pada tahun 2014, kebijakan perusahaan tentang penerapan 5R muncul sehingga penerapan 5R ini didukung penuh oleh perusahaan. Evaluasi penerapan 5R ini meliputi 5 area termasuk area terbuka dan workshop yang sudah menerapkan 5R dengan baik. Simpulan penelitian ini adalah penerapan 5R di PT. INKA (Persero) Madiun perlu peningkatan dan dukungan dari top level management.
\end{abstract}

Kata kunci: rapi, rajin, rawat, resik, ringkas

\section{PENDAHULUAN}

Perubahan zaman semakin maju dan perkembangan teknologi yang semakin canggih menghasilkan berbagai inovasi dalam berbagai bidang kehidupan, termasuk bidang industri. Kemajuan ini memberikan banyak manfaat bila dapat dinikmati oleh banyak pihak (Jahja, 2009). Teknologi canggih saat ini banyak diterapkan dalam sektor industri terutama pada unit produksi seperti penggunaan mesin untuk melakukan proses produksi. Pelaksanaan proses produksi banyak menggunakan tenaga kerja manusia. Setiap kegiatan produksi terdapat potensi bahaya yang dapat 
mengancam keselamatan dan kesehatan tenaga kerja. Potensi bahaya dapat berasal dari mesin, peralatan, lingkungan kerja ataupun dari manusia. Potensi bahaya yang tidak dikelola dengan baik dapat menimbulkan kecelakaan kerja maupun penyakit akibat kerja sehingga mempengaruhi produktivitas pekerja itu sendiri.

Angka kecelakaan kerja di Indonesia termasuk di Jawa Timur cukup besar. Secara nasional angka kecelakaan kerja untuk tahun 2015 mencapai 105.182 kasus dengan jumlah tenaga kerja yang meninggal sebanyak 2.275 orang. Sementara Dinas Tenaga Kerja dan Kependudukan Provinsi Jawa Timur mencatat pada triwulan pertama tahun 2015 jumlah kecelakaan kerja sebanyak 2.180 orang kemudian triwulan kedua sebanyak 3.099 orang dan triwulan ketiga sebanyak 5.113 orang (Disnakertransduk, 2016).

Salah satu cara yang dapat dilakukan sebagai upaya pencegahan kecelakaan kerja, penyakit akibat kerja dan meningkatkan produktivitas kerja adalah dengan memelihara lingkungan kerja dengan penerapan 5R. Sasaran dari penerapan 5R adalah pengelolaan lingkungan kerja secara fisik. Lingkungan kerja memiliki peranan yang penting terhadap keselamatan dan kesehatan tenaga kerja. Tempat kerja yang baik adalah tempat kerja yang aman. Lingkungan kerja yang menyenangkan dan serasi akan mendukung tingkat keselamatan (Ramli, 2010). Untuk menciptakan lingkungan kerja yang bersih, rapi, aman dan nyaman yang diatur oleh Peraturan Menteri Perburuhan No. 7 Tahun 1964 maka pemeliharaan housekeeping yang baik perlu diterapkan di tempat kerja.

Sistem Housekeeping diterapkan karena terjadi ketidakteraturan penempatan tools di tempat kerja, baik di kantor maupun di tempat produksi. Program $5 R$ diharapkan menghilangkan pemborosan yang ada dapat diminimalkan sehingga terjadi peningkatan produktivitas dan efektivitas dari perusahaan (Osada, 2011). Tempat kerja yang bersih, nyaman, serta teratur dapat menciptakan suasana kerja yang nyaman. Suasana nyaman di tempat kerja dapat mendorong semangat tenaga kerja yang akan berpengaruh terhadap peningkatan produktivitas. Ketatarumahtanggaan (house keeping) pertama kali diperkenalkan oleh Hiroyuki Hirano dengan konsep 5S (Seiri, Seiton, Seiso, Seiketsu, Shitsuke) pada tahun 1980 di Jepang (International Trade Centre, 2012).

Banyak sekali manfaat dari penerapan $5 \mathrm{R}$ di perusahaan, manfaat tersebut akan berpengaruh pada perubahan sikap, tingkah laku atau pola pikir manajemen dan pekerja terhadap peningkatan mutu dan produktivitas. Menurut (BP2TK) 2003, penerapan 5R memberikan keuntungan antara lain: zero waste yang berarti efisiensi meningkat dan juga mengurangi biaya, zero injury yang berarti keselamatan kerja berjalan dengan baik, zero breakdown berarti pemeliharaan lebih baik, zero defect berarti kualitas barang lebih baik, zero set up time berarti tidak ada waktu yang terbuang karena kecelakaan, zero late delivery, zero customer berarti permintaan dari konsumen tepat waktu dan zero defisit berarti perusahaan tidak mengalami defisit keuangan sehingga perusahaan akan maju

Di Indonesia konsep 5S disingkat dengan 5R yaitu Ringkas, Rapi, Resik, Rawat, Rajin. Sistem $5 \mathrm{R}$ merupakan sistem yang berasal dari Jepang yang merupakan dasar dari segala program peningkatan mutu dan produktivitas sebuah perusahaan. Tempat kerja yang bersih, nyaman, serta teratur dapat menciptakan suasana kerja yang nyaman. Suasana nyaman di tempat kerja dapat mendorong semangat tenaga kerja yang akan berpengaruh terhadap peningkatan produktivitas

Penerapan program 5R merupakan langkah awal pencegahan kecelakaan kerja yang dapat mendukung tercapainya penerapan kesehatan dan keselamatan kerja di tempat kerja. Penerapan 5R sangat penting dan bermanfaat untuk mendukung kegiatan produksi di perusahaan. 5R merupakan salah satu aspek yang harus dilaksanakan dalam program keselamatan kerja sebab dengan ketatarumahtanggaan yang baik di lingkungan kerja dapat menekan peluang kecelakaan kerja yang akan meningkatkan produktivitas perusahaan dan meningkatkan kesejahteraan tenaga kerja.

PT Industri Kereta Api atau PT INKA (Persero) merupakan Badan Usaha Milik Negara Industri Strategis yang bergerak di bidang industri sarana kereta api diantaranya Kereta Penumpang, Gerbong Barang, KRL, KRD/KRDE, Lokomotif, dan produk lainnya yang berkaitan dengan perkeretaapian. Dalam produksi kereta api itu sendiri meliputi bagian pengerjaan plat, bagian perakitan, bagian pengecatan, bagian pemasangan komponen, bagian permesinan, bagian interior dan didukung oleh bagian quality control, bagian perencanaan dan pengendalian produksi serta bagian quality assurance. Tujuan dari penelitian ini yaitu untuk mengevaluasi penerapan program $5 \mathrm{R}$ pada area workshop dan area terbuka di PT. INKA (Persero) Madiun. 
Pelaksanaan evaluasi penerapan 5R pada area workshop/gudang dikarenakan banyak sekali masalah $5 \mathrm{R}$ yang masih belum terselesaikan dengan baik yang akan berdampak pada aktivitas pekerja dan juga membahayakan pekerja seperti adanya ceceran oli pada gedung pemeliharaan, terdapat genangan air gedung serbaguna pada saat proses reforming agar kereta menjadi rata, gedung piping dan gedung wiring masih belum memiliki tempat sampah domestik sehingga sampah dibuang di kotak scrab.

Penerapan evaluasi 5R pada area workshop/ gudang, penelitian ini mengevaluasi pada area terbuka dengan masalah debu yang dominan, area terbuka sangat luas sehingga debu produksi beterbangan bercampur dengan debu lingkungan yang ada di PT. INKA (Persero) Madiun.

\section{METODE}

Penelitian ini merupakan penelitian observasional dan bersifat deskriptif dengan cara menggambarkan suatu keadaan tertentu dengan melakukan wawancara pada responden dan melakukan pengamatan menggunakan lembar observasi berupa checklist 5R. Dari segi waktu, penelitian ini termasuk dalam penelitian cross sectional yaitu keseluruhan variabel penelitian diamati secara serentak dalam satu waktu (Notoatmodjo, 2012).

Objek penelitian yaitu pada seluruh area di PT. INKA (Persero) Madiun terkhususnya pada area wokshop/gudang dan area terbuka dan populasi penelitian adalah pejabat yang berwenang pada masing-masing area. Lembar observasi yang berupa checklist disediakan oleh perusahaan akan ditandatangani oleh manager atau supervisor yang menjabat pada area tersebut.

Lokasi penelitian pada PT. INKA (Persero) berkedudukan di desa Madiun Lor Kecamatan Mangunharjo Kotamadya Madiun dengan lokasi di Jalan Yos Sudarso 71 Madiun. Waktu penelitian evaluasi penerapan 5R di PT. INKA (Persero) Madiun pada Maret 2017 selama 1 bulan.

Variabel dalam penelitian ini meliputi penerapan ringkas, penerapan rapi, penerapan resik, penerapan rawat, dan penerapan rajin pada masing-masing area yaitu area perkantoran, area workshop/gudang, area terbuka, dan area loker.

Teknik pengumpulan data menggunakan panduan wawancara dan lembar checklist 5R. setelah melakukan pengambilan data lalu diolah secara deskriptif dengan merekap hasil temuan per minggunya dan dievaluasi pada akhir bulan sehingga diperoleh hasil dan gambaran yang jelas. Observasi lapangan juga masuk dalam teknik pengumpulan data dengan melihat langsung pada area workshop/ gudang dan area terbuka tentang penerapan $5 \mathrm{R}$ di PT. INKA (Persero) Madiun.

\section{HASIL}

\section{Gambaran Umum PT. INKA (Persero) Madiun}

PT. Industri Kereta Api (INKA) Madiun merupakan Badan Usaha Milik Negara Industri Strategis (BUMN-IS) yang bergerak dalam bidang manufaktur dan jasa perkeretaapian. PT. INKA (Persero) didirikan dengan Akta Notaris Imas Fatimah, SH Nomor: 51 tanggal 18 Mei 1981 oleh Menristek dan Menhub dengan luas area $225.000 \mathrm{~m}^{2}$ dan luas bangunan $93.634 \mathrm{~m}^{2}$. PT. INKA (Persero) berkedudukan di desa Madiun Lor Kecamatan Mangunharjo Kotamadya Madiun dengan lokasi di Jalan Yos Sudarso 71 Madiun. Pemilihan letak lokasi tersebut berdasarkan hasil studi tahun 1977 yang dilakukan oleh Nippon Sharyo Seizo Kaisha Ltd. Jepang. Kondisi awal pada pendirian PT. INKA (Persero) adalah penggunaan atau pengalihan segala fasilitas dan aset yang ada di Balai Yasa Perusahaan Jasa Kereta Api (PJKA) Madiun yang didirikan tahun 1884 (bertugas dalam pemeliharaan lokomotif uap) dan gudang PJKA Madiun sebagai fasilitas dasar untuk kegiatannya. Kegiatan utama PT. INKA (Persero) adalah pembuatan kereta api (gerbong barang, gerbong ballast, gerbong batubara, gerbong tangki, kereta penumpang, kereta rel diesel, kereta rel listrik), jasa perawatan besar (overhaul) perkeretaapian, perdagangan lokal, impor dan ekspor barang dan jasa yang berhubungan dengan perkeretaapian, jasa konsultasi dan rekayasa bidang perkeretaapian, pembuatan barang-barang dalam rangka program diversifikasi produk antara lain aerobridge/boarding car, grandby car, container office, track motorcar, airport trolley, automotive product dan toilet module, dan pelayanan purna jual perkeretaapian.

Pada struktur organisasi PT. INKA (Persero) Madiun yang diterapkan dengan Peraturan Direksi Nomor PER-12/INKA/2016 tentang Struktur Organisasi PT. INKA (Persero) Madiun yang dipimpin oleh seorang Direktur Utama yang secara garis besar membawahi Satuan Pengawasan Intern, Sekretaris Perusahaan, Sistem Manajemen Kualitas 
dan Produktivitas, Direktorat Administrasi dan Keuangan, Direktorat Produksi dan Teknologi, Direktorat Komersial dan beberapa divisi yaitu Divisi Keuangan, Divisi Sumber Daya Manusia, Divisi Pemasaran Produk dan Jasa KA, Divisi Pengembangan Bisnis, Divisi Logistik dan Rendal Produksi, Divisi Teknologi dan Divisi Produksi.

Visi dari PT. INKA (Persero) Madiun adalah menjadi perusahaan kelas dunia yang unggul di bidang transportasi kereta api dan transportasi perkotaan di Indonesia. Berdasarkan visi tersebut PT. INKA (Persero) dalam pengoperasiannya berpandangan untuk selalu menampilkan citra sebuah perusahaan semaksimal mungkin untuk hasil yang terbaik. Misi dari PT. INKA (Persero) Madiun adalah menciptakan solusi terpadu untuk transportasi kereta api dan perkotaan dengan keunggulan kompetitif bisnis dan teknologi produk yang tepat guna mendorong pembangunan transportasi yang berkelanjutan.

Adapun sasaran yang ingin dicapai PT. INKA (Persero) adalah menguasai sepenuhnya pasar domestik yaitu PT. Kereta Api Indonesia (KAI) dalam hal kereta baru dan kereta retrofit, gerbong baru serta angkatan darat; menembus pasar regional dan pasar negara sedang berkembang (kalau perlu bersama mitra luar negeri) dalam hal kereta, gerbong, Kereta Rel Listrik (KRL), Kereta Rel Diesel (KRD), untuk manufakturing dan rancang bangun; menjadi badan terdepan terhadap calon pesaing di dalam negeri dan regional; menjadi perusahaan yang tumbuh dan berkembang (Viable Company).

Strategi perusahaan yang digunakan PT. INKA (Persero) adalah menutup semua ketertinggalan yang selama ini belum tertangani dalam pengelolaan perusahaan; mengusahakan peningkatan pelayanan terhadap pelanggan (PT. KAI) terutama dalam hal waktu penyerahan; menyiapkan diri untuk mempunyai daya saing yang tinggi; mengusahakan selalu berada di depan dalam hal bidang usaha transportasi darat terhadap pesaing dalam negeri dan regional.

Proses produksi di PT. INKA (Persero) dilakukan secara bertahap oleh bagian pengerjaan plat, bagian perakitan, bagian pengecatan, bagian pemasangan komponen, bagian permesinan, bagian interior dan didukung oleh bagian quality control, bagian perencanaan dan pengendalian produksi serta bagian quality assurance.

\section{Kebijakan Pimpinan Perusahaan dalam Upaya Penerapan 5R di PT. INKA (Persero) Madiun}

Penerapan 5R di PT. INKA (Persero) Madiun sudah ada sejak tahun 90-an, penerapan 5R sudah sangat baik karena pada waktu itu terdapat unit khusus yang menangani masalah 5R, akan tetapi Badan Pengelola Industri Strategis (BPIS) hilang penerapan 5R di PT INKA (Persero) mulai stagnan tidak ada perubahan yang signifikan sehingga $5 \mathrm{R}$ berjalan kurang efektif dan unit khusus $5 \mathrm{R}$ juga dibubarkan sehingga penerapan 5R ini dilimpahkan kepada Departemen Pemeliharaan dan K3LH. Pada tahun berikutnya penerapan $5 \mathrm{R}$ ini tetap berjalan walaupun tidak maksimal karena dukungan dari manajemen kurang dan pada tahun 2014 mulai didukung oleh manajemen dengan membuat Surat Keputusan terkait penerapan 5R sehingga diharapkan penerapan 5R dapat dilaksanakan kembali dengan baik.

Kebijakan pimpinan perusahaan dan komitmen manajemen secara tertulis baru dikeluarkan pada tahun 2014 dengan Surat Keputusan No. 84/SK/ INKA/2014 tentang Pedoman Penerapan Budaya 5R PT. Industri Kereta Api (Persero). Walaupun kebijakan sudah ada, namun dalam pelaksanaannya 5R masih harus memulai kembali di karena pada tahun sebelum penurunan SK dari Direktur PT. INKA (Persero), penerapan 5R ini cenderung stagnan tidak ada perubahan yang signifikan oleh karena itu diluncurkan SK pada tahun 2014 agar dapat membangkitkan penerapan 5R dan sekaligus menjadi dukungan top level management untuk penerapan $5 \mathrm{R}$ yang lebih baik.

Pada SK tersebut dijelaskan bahwa dalam penerapan $5 \mathrm{R}$ terdapat skema yang harus dijalankan di PT. INKA (Persero) yaitu Persiapan Konsep dan Penetapan Tim 5R; Penetapan Standar 5R (Area Perkantoran, Area Pabrik/Gudang dan Area Limbah); Penetapan Penanggung Jawab Area 5R; Gerakan Penerapan budaya 5R dan Patroli, Audit 5R dan Reward.

Konsep dasar yang diterapkan pada PT. INKA (Persero) ini dengan menerapkan 5R di seluruh area PT INKA (Persero) hal ini menyebabkan 5R berjalan dengan baik tanpa ada ketimpangan, baik yang di kantor maupun di dalam ruang produksi yang mendasarkan standar $5 \mathrm{R}$ yang ada, setelah dilaksanakan program $5 R$ ini maka perlu adanya patrol dan audit 5R sehingga dapat dinilai sebelum dan sesudah penerapan 5R. Pelaksanaan pemeriksaan $5 \mathrm{R}$ dilakukan secara kontinyu, apabila $5 \mathrm{R}$ pada area 
atau departemen itu bagus maka berhak mendapatkan reward dan menjaga komitmen $5 \mathrm{R}$ tersebut.

Menurut buku Pedoman Penerapan 5R PT. INKA (Persero) sesuai dengan SK INKA No. 84 Tahun 2014, Tim 5R terdiri dari Ketua Tim, Wakil Ketua I, Wakil Ketua II, Wakil Ketua III, Sekretaris Tim, Anggota Tim dan Sekretariat. Tetapi untuk memudahkan pengawasan $5 \mathrm{R}$ di PT. INKA (Persero) maka job description dari 5R masuk ke dalam program Departemen Manajemen Mutu dan Lingkungan Hidup (MMLH) sehingga untuk pengecekan di lapangan dapat berjalan dengan mudah.

Patroli 5R dilakukan setiap hari dengan tim 5R yang dilakukan oleh safety officer di Dept. MMLH. Pembagian wilayah yang untuk patrol 5R ini terdiri dari beberapa kategori workshop/ gudang, perkantoran, jalan umum, kamar mandi, dan loker tenaga kerja. Pelaksanaan pemeriksaan 5R yang dilakukan oleh Tim 5R tersebut menemukan dan merekomendasi temuan ketidaksesuaian yang ditulis di lembar pemeriksaan dengan menggunakan kuesioner checklist, dan salah satu dari tim 5R ini membawa foto untuk dokumentasi agar ke depannya dapat ada perbandingan sebelum dan sesudah dinilai. Setelah itu lembar pemeriksaan akan ditandatangani oleh manajer pada area tersebut. Lembar pemeriksaan ini dapat digunakan untuk mengukur apakah pelaksanaan 5R di PT. INKA (Persero) Madiun sudah berjalan baik atau belum.

Petugas patroli 5R jika menemukan ketidaksesuaian terkait 5R maka akan dengan segera memberikan saran kepada supervisor/manager dan temuan di lapangan tersebut akan dibahas juga oleh tim 5R dalam rapat internal Dept. MMLH sehingga akan segera adanya perbaikan lebih lanjut guna untuk mencapai tujuan 5R.

Pelaksana 5R adalah partisipasi seluruh pihak dan seluruh tenaga kerja dengan saling meneladani, saling mengingatkan dan saling menegur sehingga menjadi kebiasaan yang baik guna merubah sikap perilaku individu maupun kelompok dalam perusahaan.

\section{Evaluasi Penerapan 5R di PT. INKA (Persero) Madiun (Ringkas, Rapi dan Resik)}

Penerapan 5R sudah dijalankan mulai tahun 90an yang meliputi tindakan preventif dan tindakan korektif. Tindakan preventif berupa pemberian informasi kepada seluruh pekerja dengan penyuluhan dan papan informasi 5R sedangkan tindakan korektif dilakukan oleh tim 5R dan dibantu tenaga dari Departemen Manajemen Mutu dan Lingkungan Hidup (MMLH). Sosialisasi 5R dilaksanakan pada briefing pagi pada setiap unit kerja dan pernah dilakukan apel akbar yang dipimpin langsung oleh Direktur PT. INKA (Persero). Untuk pelaksanaannya dilakukan pada setiap hari sebelum dan sesudah bekerja dan setiap hari jumat di setiap area. PT. INKA (Persero) menitikberatkan pada 3R yang pertama yaitu ringkas, rapi, resik dikarenakan paling utama, karena 3R ini yang sulit dilaksanakan oleh seluruh tenaga kerja. Penilaian 5R ini di golongan menjadi 4 area yaitu area perkantoran, area workshop/gudang, area terbuka dan area loker.

Penerapan 5R dilakukan pada setiap unit kerja tetapi pada hari Jumat mulai pukul 08.00 WIB sampai 09.00 WIB, seluruh tenaga kerja baik di workshop maupun di kantor melakukan 5R secara bersama-sama sehingga budaya $5 \mathrm{R}$ ini akan terbentuk dengan sendirinya.

\section{R Area Workshop}

Penerapan ringkas di area workshop/Gudang sudah sangat baik dikarenakan barang yang sudah rusak maupun barang yang sudah tidak digunakan lagi akan dibuang dari area kerja sehingga penerapan ringkas sudah berjalan dengan baik. Sampah sudah sangat baik dikarenakan dibedakan menjadi 3 kelompok yaitu sampah organik, sampah anorganik dan limbah B3 selain itu juga ada kotak scrab untuk membuang sisa potongan baja, namun ditemukan di beberapa workshop/gudang masih terdapat barang yang rusak tetapi tidak segera dibersihkan yang mengganggu aktivitas, ditemukan juga kebocoran baik kran air mengakibatkan genangan air yang membahayakan, pada beberapa gedung juga ditemukan tidak adanya tempat sampah domestik sehingga sampah domestik bercampur dengan sampah scrab. Untuk masalah selanjutnya, papan 5R sedikit sekali berada pada area workshop/gudang, ada di beberapa gedung namun papan sudah usang dan harus diperbarui kembali, pada gedung welding terdapat tabung gas $\mathrm{CO}_{2}$ yang tidak terpakai dan sudah tidak digunakan namun tabung tersebut masih di sana sehingga mengurangi tempat penyimpanan alat welding.

Pada penerapan rapi, pembagian daerah dan tanda penempatan masih belum maksimal dikarenakan banyak sekali barang-barang yang melebihi pembatas/garis kuning yang berada di workshop/gudang hal ini menyebabkan dapat 
tersandung apabila tidak hati-hati berjalan. Pada penataan APD masih belum tertata dengan rapi dikarenakan ada beberapa APD seperti safety gloves maupun safety helmet tidak tertata dengan rapi. Selain itu penataan alat yang tidak rapi menyebabkan produktivitas menurun karena sulit mencari alat pada gedung perakitan. Penempatan barang yang tidak sesuai akan mengurangi nilai dari rapi, seperti pada gedung perakitan tempat rak alat dijadikan tempat helm sehingga tidak sesuai dengan fungsinya. Pada gedung GRFP, alat pembersih seperti sapu dan cikrak masih diletakkan pada sembarang tempat karena belum ada tempat khusus alat kebersihan.

Penerapan 5R khususnya resik di workshop/ gudang cukup baik walaupun masalah utama pada workshop/gudang sama yaitu debu. Debu dihasilkan dari aktivitas proses produksi yang begitu banyak akan tetapi setiap selesai bekerja, pekerja selalu membersihkan tempat kerja mereka. Selain dari debu, untuk sumber kotor lainnya seperti air masih ada dikarenakan kran air terkadang ada yang bocor dan membuat genangan, selain itu air yang digunakan untuk mendinginkan pada saat pemotongan plat ada juga yang mengenang dan masuk pada sela-sela rel kereta api hal ini menjadikan sumber kotor. Alat kerja dan mesin terpelihara dengan baik namun di gedung pemeliharaan terdapat alat kerja yang terkena oli bekas.

\section{R Area Terbuka}

Pada semua area terbuka mulai dari pintu masuk utama PT. INKA (Persero) hingga area scrap kondisi ringkas dalam kondisi baik. Dari pengamatan dan lembar kuesioner, terdapat tumpukan material bekas bangunan di sembarang tempat pada area terbuka yang sedang membuat tutup selokan menggunakan beton, namun campuran semen tersebut membuat selokan menjadi tersumbat.

Penerapan rapi pada area terbuka sudah berjalan baik taman sudah tertata dengan baik tidak ada sampah dedaunan hanya kurang variasi tanaman taman. Saluran air sudah ada namun terjadi pendangkalan, saluran tersebut tidak lancar akibat adanya dedaunan, debu, dan terkadang juga ada plat kecil sehingga aliran air tidak lancar. Agar terlihat lebih rapi, PT. INKA (Persero) berupaya untuk memberikan tutup menggunakan cor walaupun dilakukan secara bertahap.

Penerapan resik pada area taman sudah baik karena tidak ada dedaunan yang berserakan, sampah ranting, dan lainnya. Taman selalu dibersihkan oleh cleaning service secara berkala sehingga selalu bersih namun terkadang masih saja ada putung rokok di taman maupun pada pot bunga. Temuan selanjutnya, saluran air masih berfungsi hanya saja terjadi pendakalan. Debu masih banyak ditemukan pada area terbuka.

\section{Evaluasi Penerapan Rawat dan Rajin di Area Workshop/Gudang dan Area Terbuka PT. INKA (Persero) Madiun}

Penerapan Rawat dan Rajin pada 4 area di PT. INKA (Persero) Madiun yaitu area terbuka dan workshop/gudang sudah dilakukan dengan baik namun belum ada indikator keberhasilan atau lembar checklist karena perusahaan menekankan pada ringkas, rapi, dan resik. 3R pertama sangat dilakukan di perusahaan ini mengingat penerapan $5 \mathrm{R}$ pernah berhenti sehingga harus dibangun dari awal kembali budaya 5R di PT. INKA (Persero) Madiun.

Penerapan rawat dan rajin merupakan kelanjutan dari $3 \mathrm{R}$ yang pertama, apabila $3 \mathrm{R}$ sudah terpenuhi dan berjalan dengan baik maka rawat dan rajin akan otomatis berjalan dengan baik juga karena sudah menjadi budaya bagi setiap tenaga kerja yang melakukan 5R.

Inti dari penerapan $5 \mathrm{R}$ yaitu pada $3 \mathrm{R}$ yang pertama, apabila $3 \mathrm{R}$ pertama sudah berjalan dengan baik dan menjadi budaya bagi pekerja maupun manajemen maka $\mathrm{R}$ selanjutnya akan berjalan seiringan. Rawat dan Rajin merupakan implementasi dari Ringkas, Rapi, Resik yang saling berkaitan sehingga tidak boleh berjalan dengan timpang.

\section{PEMBAHASAN}

\section{Evaluasi Penerapan 5R di PT. INKA (Persero) Madiun}

Penerapan 5R di PT. INKA (Persero) sempat terhenti tidak ada perubahan, dukungan yang kurang dari pihak top management memengaruhi kinerja penerapan $5 R$. penerapan $5 R$ ini membutuhkan kerja sama antar semua pihak dari pihak pimpinan perusahaan hingga tenaga kerja agar mencapai penerapan 5R yang baik. Pada tahun 2014 dikeluarkan Surat Keputusan No. 84/SK/INKA/2014 tentang Pedoman Penerapan Budaya 5R PT. Industri Kereta Api (Persero) sehingga penerapan 5R berjalan tetapi masih belum maksimal karena memulai dari awal 5R sangat sulit, membutuhkan kerja sama antar lini. Hadirnya SK dari pimpinan, penerapan 5R sudah didukung penuh oleh pimpinan perusahaan 
sehingga $5 \mathrm{R}$ berjalan dengan baik. Pelaksanaan secara serentak dilakukan pada hari Jumat yang dilakukan selama 1 jam sebelum memulai bekerja di setiap area.

Menurut Sukmawati (2005), dukungan pimpinan perusahaan sangat diperlukan dalam pelaksanaan 5R, tanpa dukungan pimpinan pelaksanaan 5R akan sulit berhasil. Teladan sangat penting dan berpengaruh pada tenaga kerja, pimpinan yang meninjau ke area kerja akan menjadi pemacu semangat bagi seluruh tenaga kerja.

Contoh dari kebijakan yang dibuat oleh pihak manajemen perusahaan kepada seluruh tenaga kerja agar dapat menerapkan 5R secara maksimal dengan membuat surat keputusan yang tertulis dan yang kedua membuat tim audit dan patroli $5 \mathrm{R}$ sesuai tugasnya masing-masing.

Pengecekan oleh tim audit dilaksanakan setiap minggu dan pada akhir bulan diadakan evaluasi $5 \mathrm{R}$, dari temuan per minggu akan diberikan solusi bersama untuk perbaikan guna meningkatkan produktivitas dan menghindari kecelakaan kerja. Pertemuan tersebut dibahas secara bersama-sama.

Oleh karena itu, PT. INKA (Persero) sudah memiliki komitmen terhadap penerapan 5R yang didukung dengan pimpinan perusahaan dan seluruh tenaga kerja dengan mengeluarkan Surat Keputusan No. 84/SK/INKA/2014 tentang Pedoman Penerapan Budaya 5R PT. Industri Kereta Api (Persero) untuk mengikuti peraturan Undang-Undang No. 1 Tahun 1970 tentang Keselamatan Kerja Bab III pasal 3 ayat 1 huruf D dan Peraturan Menteri Perburuhan No. 7 Tahun 1964 tentang Syarat Kesehatan, Kebersihan serta Penerangan dalam Tempat Kerja.

\section{R Area Workshop}

Pada area workshop/gudang masih ditemukan barang-barang yang rusak tercampur dengan barang yang masih berfungsi, ketika pekerja membutuhkan barang tersebut secara cepat bisa terjadi kesalahan karena barang tersebut tercampur sehingga perlu adanya rekomendasi untuk segera menyingkirkan barang yang tidak digunakan ataupun rusak. Menurut Hirano (1995), ringkas adalah kegiatan memisahkan suatu barang yang masih digunakan dan yang tidak digunakan agar barang yang masih digunakan. Kran air yang bocor menyebabkan kerugian pada perusahaan, selain dari biaya yang dikeluarkan bahaya selanjutnya yaitu terpeleset. Pekerja yang tidak hati-hati pada area workshop/gudang terutama pada unit reforming akan terpeleset. Banyak sekali genangan air yang terjadi karena proses reforming dan bocornya pipa air sehingga rekomendasi untuk selalu membersihkan air dilakukan secara berkala dan dilakukan penggantian kran air yang bocor tersebut agar perusahaan tidak merugi. Pada beberapa gedung tidak ditemukan tempat sampah domestik sehingga sampah domestik dibuang pada kotak scrab. Hal ini sebaiknya dihindarkan karena kotak scrab akan langsung di proses kembali menjadi baja, apabila terdapat sampah domestik, maka pekerja yang ada di penampungan $s c r a b$ akan memilah sehingga membuang waktu yang cukup lama maka disarankan untuk memberikan kotak sampah domestik. Papan 5R juga sangat minim di area workshop, di beberapa gedung juga ada papan informasi $5 \mathrm{R}$ tetapi sudah usang sehingga harus dilakukan pemasangan banner tentang informasi $5 R$ sehingga pekerja akan selalu ingat dengan budaya $5 \mathrm{R}$, budaya $5 \mathrm{R}$ sangat menguntungkan bagi pekerja dan perusahaan. Tabung gas $\mathrm{CO}_{2}$ yang berukuran besar pada gedung welding yang sudah terpakai seharusnya bisa dibongkar dan dikembalikan pada supplier sehingga ruangan itu dapat digunakan untuk penyimpanan alat las yang selama ini diletakkan di depan tabung gas $\mathrm{CO}_{2}$.

Penerapan rapi pada workshop/gudang menitikberatkan pada pembagian daerah dan tanda pembatas yang memisahkan untuk berjalan dan penempatan barang atau area kerja. Cat yang memudar dapat mengakibatkan orang lalai dalam berjalan kaki maupun menempatkan barang, sehingga perlu untuk mengecat ulang. Penempatan yang APD kurang rapi di beberapa area workshop/ gudang dikarenakan kurangnya tempat penyimpanan APD. APD diletakkan di sembarang tempat sehingga terlihat tidak rapi yang seharusnya dibuatkan tempat khusus untuk APD sehingga apabila membutuhkan langsung ke tempat tersebut. Penempatan alat yang kurang rapi akan membuat pekerja bingung dan mengurangi produktivitas karena mencari alat yang dibutuhkan, hal ini perlu dihindari dengan memberikan rak alat dengan pembatas alat yang banyak digunakan dan alat yang jarang digunakan akan tetapi alat harus tertata dengan rapi. Menempatkan barang atau alat sesuai dengan tempatnya agar mudah mencarinya sesuai dengan penerapan rapi. Tempat penyimpanan alat kebersihan pada area workshop masih belum ada, pada gedung GRFP alat kebersihan masih tercecer sehingga pekerja akan kesulitan dalam membersihkan area kerja. Perlunya pembuatan rak khusus alat kebersihan pada yang ditempatkan di pojok agar 
mudah terlihat dan tidak mencari alat kebersihan apabila mau membersihkan area kerja.

Pada penerapan resik, air yang menggenang masih terlihat di area workshop akibat dari proses reforming yang dijelaskan pada penerapan ringkas. Hal ini perlu dilakukan pembersihan secara berkala agar kecelakaan dapat terhindarkan. Debu juga ada di semua area workshop/gudang oleh karena proses produksi, debu ini setiap hari akan dibersihkan oleh pekerja sebelum dan sesudah bekerja sehingga intensitas debu dapat ditekan, selain itu PT. INKA (Persero) menyiapkan alat kebersihan di setiap workshop/gudang seperti sapu, lantai akan disiram air terlebih dahulu setelah itu akan di sapu. Debu baja ini nantinya akan dimasukkan ke dalam kotak scrap dan akan diangkut ke unit scrap.

\section{R Area Terbuka}

Pada area terbuka, masalah yang ditemukan pada saat patroli $5 \mathrm{R}$ yaitu saluran air yang tersumbat oleh karena dedaunan dan tidak tertutup pada sebagian tempat. Saluran air yang tidak lancar menyebabkan adanya sarang nyamuk dan sampah dedaunan menumpuk mengakibatkan terjadinya pendangkalan. Pada waktu hujan pernah mengalami kebanjiran akibat saluran yang kurang lancar. Akibatnya proses produksi sempat terhenti karena banjir yang membuat kerugian dan produktivitas menurun. Debu pada area terbuka menjadi masalah utama pada perusahaan ini sehingga untuk mengatasi debu dengan membuat program INKA BEBAS DEBU yang diimplementasikan dengan pengaspalan, penanaman pohon dan membuat taman, menyirami secara berkala untuk menyesuaikan peraturan yang ada. PT. INKA (Persero) terus berupaya pada pembenahan selokan dengan membersihkan selokan secara bertahap dan penutupan selokan yang sesuai dengan Peraturan Menteri Perburuhan No. 7 Tahun 1964 Pasal 3.

\section{Evaluasi Penerapan Rawat dan Rajin di Seluruh Area PT. INKA (Persero) Madiun}

Rawat pada prinsipnya mengusahakan agar tempat kerja yang sudah menjadi baik dapat selalu terpelihara (Jahja, 1995), apabila 3R diatas sudah terlaksana maka secara otomatis akan merawat area kerja masing-masing misalnya pada area workshop/ gudang sudah ada jadwal pemeriksaan untuk masingmasing mesin, adanya safety sign pada area kerja di semua workshop/gudang, melakukan perawatan pada forklift, merawat alat kerja dsb. Sehingga barang tersebut tidak mudah rusak karena dirawat baik oleh pekerja.

Prinsip rajin di tempat kerja adalah lakukan apa yang harus dilakukan dan menghindari apa yang tidak boleh dilakukan di tempat kerja (Jahja, 1995). Hal yang mendasar pada penerapan rajin yaitu contoh dari atasan. Atasan yang memiliki prinsip 5R yang sudah baik pasti akan ditiru oleh tenaga kerja yang lain yang membuat merasa malu apabila tidak melakukan 5R. penerapan resik sendiri akan secara otomatis dilakukan apabila 4R yang pertama sudah dilaksanakan dan rasa kepedulian pada lingkungan kerja sudah sangat tinggi. Pada PT. INKA (Persero) sudah menerapkan $5 \mathrm{R}$ namun masih belum optimal tetapi PT INKA (Persero) terus berupaya untuk membenahi penerapan 5R, salah satunya pejabat struktural yang terdiri dari General Manager, Senior Manager, dan Manager selalu memberikan dukungan dan contoh untuk penerapan $5 \mathrm{R}$ tetapi juga tidak lepas dari $4 \mathrm{R}$ sebelumnya, sehingga tenaga kerja lebih semangat dalam menerapkan rajin karena atasan mereka juga menerapkan. Pekerja akan merasa malu apabila tidak melakukan prinsip rajin dan meniru prinsip rajin dari atasan.

\section{SIMPULAN}

Pimpinan PT. INKA (Persero) Madiun telah mengeluarkan kebijakan tentang pedoman penerapan 5R di PT INKA (Persero) Madiun sesuai dengan Surat Keputusan No. 84/SK/INKA/2014 tanggal 28 Oktober 2014. Peranan tim 5R sebagai penggerak pelaksanaan 5R yang oleh Dept. MMLH dan masing-masing unit juga memiliki perwakilan tim 5R yang bertugas meliputi pembuatan jadwal pelaksanaan pemeriksaan $5 \mathrm{R}$, pembagian tanggung jawab pada masing-masing unit terhadap penerapan $5 \mathrm{R}$, memantau serta mengevaluasi hasil pemeriksaan $5 \mathrm{R}$.

Penerapan 5R di PT. INKA (Persero) Madiun mulai ditingkatkan kembali setelah beberapa tahun tidak ada perubahan yang signifikan dari penerapan 5R. Pada tahun 2014, pimpinan mengeluarkan Surat Keputusan No. 84/SK/INKA/2014 yang agar penerapan $5 \mathrm{R}$ berjalan maksimal dengan dukungan top level management.

Pada area workshop/gudang masih ditemukan genangan air akibat aktivitas produksi maupun kran bocor, ada beberapa komponen kereta keluar dari garis kuning dan cat garis warna kuning sudah 
memudar, ada beberapa APD yang masih diletakkan tidak di rak, papan 5R yang sudah usang, tabung gas $\mathrm{CO}_{2}$ yang sudah tidak digunakan lagi.

Pada area terbuka masih banyak ditemukan debu tetapi dalam hal ini sedang dalam proses perbaikan untuk menjadikan program INKA Bebas Debu tercapai, selokan tersumbat oleh cor karena pembangunan, masih ditemukan sampah domestik pada kotak scrab.

\section{DAFTAR PUSTAKA}

Balai Pengembangan Produktivitas Tenaga Kerja (BP2TK)., 2003. Konsep dan Penerapan 5S. Surabaya: Dinas Tenaga Kerja.

Balai Pengembangan Produktivitas Tenaga Kerja (BP2TK)., 2003. Pedoman Penilaian dan Sertifikasi Penerapan 5R di Perusahaan Jawa Timur. Disnaker.

Dinas Tenaga Kerja dan Transmigrasi Penduduk., 2016. Disnakertransduk Jatim: Angka Kecelakaan Kerja di Jatim Capai Ribuan Orang. Surabaya: Disnakertrans Provinsi Jawa Timur. http://kominfo. jatimprov.go.id/read/umum/disnakertransdukjatim-angka-kecelakaan-kerja-di-jatim-capairibuan-orang (Sitasi 2 Mei 2016).

Hirano, H., 1995. Penerapan $5 S$ di Tempat Kerja. Jakarta: PQM Consultants.
International Trade Center., 2012. 5S: Good Housekeeping Techniques for Enhancing Productivity, Quality and Safety at The Workplace. Export Quality Bulletin. Geneva: International Trade Centre.

Jahja, K., 2009. 5R (Ringkas, Rapi, Resik, Rawat, Rajin) Dasar Membangun Industri Kelas Dunia. Jakarta: PQM Consultants.

Notoatmodjo, S., 2012. Metodologi Penelitian Kesehatan. Jakarta: Rhineka Cipta.

Osada, T., 2011. Sikap Kerja 5S. Cetakan ke-4, Jakarta: PPM.

Peraturan Menteri Perburuhan Nomor 7 Tahun 1964 tentang Syarat-syarat Kesehatan, Kebersihan, serta Penerangan di Tempat Kerja. Jakarta: Departemen Perburuhan.

PT. INKA (Persero)., 2014. Pedoman Penerapan Budaya 5R PT. INKA (Persero). Madiun: PT. INKA (Persero).

Ramli, S., 2010. Sistem Manajemen Keselamatan \& Kesehatan Kerja OHSAS 18001. Jakarta: Dian Rakyat.

Sukmawati, R., 2005. Pelaksanaan 5R di Balai Pengobatan PT. Kertas Leces. Tugas Akhir. Surabaya: Universitas Airlangga.

Undang-Undang Nomor 1 Tahun 1970 tentang Keselamatan Kerja. Jakarta: Departemen Perburuhan. 